University of Vermont

UVM ScholarWorks

College of Agriculture and Life Sciences Faculty

Publications

4-1-2017

\title{
The use of extrafloral nectar in pest management: overcoming context dependence
}

lan Matthew Jones

Florida International University

Suzanne Koptur

Florida International University

Eric J. von Wettberg

Florida International University

Follow this and additional works at: https://scholarworks.uvm.edu/calsfac

Part of the Agriculture Commons, and the Sustainability Commons

\section{Recommended Citation}

Jones IM, Koptur S, von Wettberg EJ. The use of extrafloral nectar in pest management: overcoming context dependence. Journal of Applied Ecology. 2017 Apr;54(2):489-99.

This Article is brought to you for free and open access by the College of Agriculture and Life Sciences at UVM ScholarWorks. It has been accepted for inclusion in College of Agriculture and Life Sciences Faculty Publications by an authorized administrator of UVM ScholarWorks. For more information, please contact scholarworks@uvm.edu. 


\title{
REVIEW
}

\section{The use of extrafloral nectar in pest management: overcoming context dependence}

\author{
lan Matthew Jones ${ }^{1 *}$, Suzanne Koptur ${ }^{1,2,3}$ and Eric J. von Wettberg ${ }^{1,2,3}$ \\ ${ }^{1}$ Department of Biological Sciences, Florida International University, 11200 SW 8th St., Miami, FL 33199, USA; \\ ${ }^{2}$ Department of Earth and Environment, Agroecology Program, Florida International University, 11200 SW 8th St., \\ ECS 157, Miami, FL 33199, USA; and ${ }^{3}$ International Center for Tropical Botany, College of Arts \& Sciences, Florida \\ International University, 11200 SW 8th St., ECS 450, Miami, FL 33199, USA
}

\begin{abstract}
Summary
1. Extrafloral nectar (EFN) provides plants with indirect defence against herbivores by attracting predatory insects, predominantly ants. Decades of research have supported the role of EFN as an effective plant defence, dating back to Thomas Belt's description of ants on acacia in 1874 . 2. Despite this extensive body of literature, knowledge of the ecological role of EFN has rarely been applied in the field of pest management. We review the existing literature on the use of EFN in agriculture and consider the obstacles that have hindered this transition.

3. Chief among these obstacles is the influence of ecological context on the outcome of EFN-mediated interactions. As such, we consider the options for various agricultural systems in the light of the growth habit of EFN-producing species, focusing first on orchard species and then on herbaceous crops. In each case, we highlight the benefits and difficulties of utilizing EFN as a pest management tool and of measuring its efficacy.

4. Synthesis and applications. We argue that it is time for a shift in extrafloral nectar (EFN) research towards applied settings and seek to address the question: How can a context-dependent and often inducible plant trait be utilized as a reliable tool in agricultural pest management? Breeding crops for increased EFN production, and intercropping with EFN-producing plants, can enhance assemblages of beneficial insects in many agricultural settings. Orchard systems, in particular, provide an ecological context in which the attraction of ants can contribute to cost-effective and sustainable pest management programmes over a broad geographic range.
\end{abstract}

Key-words: agriculture, ants, biological control, extrafloral nectar, nectaries, orchard crops, pest management, plant defence

\section{Introduction}

Extrafloral nectaries (EFNs) are nectar-secreting glands located outside of flowers and have been observed on a vast diversity of species, spanning over 93 families and 332 genera (Koptur 1992a; Marazzi, Bronstein \& Koptur 2013). These nectaries may serve diverse ecological functions (Baker, Hall \& Thorpe 1978; Becerra \& Venable 1989; Wagner \& Kay 2002; Heil 2011), but they are best known for providing plants with indirect defence against herbivores by attracting predatory insects, predominantly ants (Bentley 1977b; Koptur 1992a; Rosumek et al. 2009; Heil 2015).
Extrafloral nectar-producing plants can be divided into two groups based on the nature of their interactions with ants. Myrmecophytes usually provide domatia and food bodies as well as EFN and engage in obligate interactions with ants. Acacia cornigera trees in Central America, for example, often succumb to herbivory when resident Pseudomyrmex ferruginea ants are experimentally removed (Janzen 1966). A far greater number of plants, however, including all of the cultivated species mentioned in this review, fall into the category of myrmecophiles. Myrmecophiles provide only EFN and engage in facultative interactions with ants. Although their interactions with ants are more varied in their outcomes (Rosumek et al. 2009), significant fitness benefits have been reported in many plants (Koptur 1979; Oliveira 1997; Rudgers 2004; Kost \& Heil 2005; Leal et al. 2006; Koptur et al. 2013). 
The production of EFN has often been shown to be induced by insect damage (Koptur 1989; Agrawal \& Rutter 1998; Heil et al. 2001a). Both the volume of nectar produced by each nectary (Heil et al. 2001a) and the number of nectaries (Mondor \& Addicott 2003) have been seen to increase in damaged or herbivore infested plants. This plasticity confers several key benefits to plants. Metabolic costs are reduced when EFN production is low, and the variable expression of defensive traits also provides a barrier against the evolution of insect resistance (Heil 2010). In addition to responding to leaf damage, EFN production has been observed to vary with plant age (Boege \& Marquis 2005; Kwok \& Laird 2012; Quintero, Barton \& Boege 2013) and with the age of individual leaves (Heil et al. 2000a). Young leaves are nutrient rich (Radhika et al. 2008) and are necessarily soft to allow for cell expansion (Yamawo et al. 2012). As a result, young leaves are particularly susceptible to herbivory. Optimal defence theory predicts that plant parts that are of particularly high value, or that are highly vulnerable to herbivory, should exhibit heightened defences (McKey 1974). Several plant species have been shown to produce EFN in patterns predictable by optimal defence theory (Heil et al. 2004a; Wäckers \& Bonifay 2004; Jones \& Koptur 2015a). These studies highlight the ability of plants to manipulate the activity of beneficial insects, while minimizing costs.

The mutualism between plants and defensive ants was first described by Thomas Belt (1874) and, since that time, many studies have identified food-for-protection mutualisms between ants and plants (reviewed in Bentley 1977a,b; Koptur 1992a; Rosumek et al. 2009). In addition to ants, EFN has often been shown to attract and enhance the performance of other predators (Wang et al. 2014; Koptur, Jones \& Pena 2015) and parasitoids (Irvin et al. 2014; Jamont, Dubois-Pot \& Jaloux 2014; Irvin \& Hoddle 2015). Our knowledge to date suggests that commercial and subsistence growers could strongly benefit from the use of EFN-producing plants, either as primary crops, or as companion plants to attract natural enemies (Bugg \& Dutcher 1989; Heil 2015). Despite this obvious potential, relatively little attention has been paid to the role of EFN in crop plants, and strikingly few studies have taken place in agricultural settings. Here, we review the existing literature in this area, focussing on crop plants with a range of growth habits. We go on to discuss the obstacles that have hindered the transition of EFN research from ecological theory to applied pest management. Finally, we present ideas for overcoming these obstacles and suggest areas for future research.

\section{Extrafloral nectar in orchard crops}

Orchard crops represent a promising area for the use of EFN in biological control programmes. The longevity of the plants and the lack of disturbance, relative to other agricultural settings, give orchard habitats the potential to support and sustain populations of beneficial insects. Intercropping with EFN-producing species that support natural enemies is also possible in orchard settings, with little or no sacrifice to the primary crop. For example, the use of hairy vetch, Vicia villosa, as a cool season cover crop has been observed to increase the numbers of predatory lady beetles in pecan orchards (Bugg, Dutcher \& McNeil 1991). Other EFN-producing species such as sunflower, Helianthus annuus, and cowpea, Vigna unguiculata, have shown potential as warm season cover crops for pecan that might enhance biological control while also providing an additional commercial outlet for growers (Bugg \& Dutcher 1989).

Many tree species produce EFN, and commercially important species are taxonomically scattered (Table 1). Extrafloral nectaries have been described in rubber (Euphorbiaceae) (Frey-Wyssling 1933), mahogany (Meliaceae) (Lersten \& Rugenstein 1982; Peng, Christian \& Reilly 2010) and cashew (Anacardiaceae) (Rickson \& Rickson 1998), but the best-studied family in this regard is the Rosaceae. Several commonly cultivated species in the family Rosaceae produce EFN in abundance, including cherry, Prunus avium (Yee 2008), almond, Prunus dulcis (Limburg \& Rosenheim 2001), and peach, Prunus persica (Mathews, Brown \& Bottrell 2007; Mathews, Bottrell \& Brown 2009). In almond orchards, for example, EFN has been observed to support the omnivorous lacewing, Chrysoperla plorabunda (Limburg \& Rosenheim 2001). The presence of EFN enhanced the longevity of first-instar lacewing larvae and allowed them to maintain high levels of searching activity (Limburg \& Rosenheim 2001).

Extrafloral nectar in peaches has been studied in greater detail, and several studies indicate the importance of EFN for plant protection in this orchard crop (Mathews 2005; Mathews, Brown \& Bottrell 2007; Mathews, Bottrell \& Brown 2009, 2011). Mathews, Bottrell \& Brown (2009) compared peach trees from a single cultivar (Lovell) with a nectaried and a nectariless phenotype. In the first year following planting, trees with EFNs attracted higher densities of defensive ants and harboured fewer herbivores than trees without EFNs. Trees with EFNs also experienced lower folivory, increased trunk growth and, most significantly, enhanced fruit production. In subsequent years, trees with EFNs produced three times more buds than those without EFNs and supported more diverse arthropod communities (Mathews, Bottrell \& Brown 2009). The oriental fruit moth, Grapholita molesta, is an important economic pest of peach orchards, and its numbers have been shown to be reduced on peach trees with EFNs (Mathews, Brown \& Bottrell 2007; Mathews, Bottrell \& Brown 2011). Crucially, G. molesta inflicted $90 \%$ less damage to fruit on trees with EFNs, indicating that EFN in peach orchards has a protective role for fruit as well as reducing foliar herbivory (Mathews, Brown \& Bottrell 2007). These findings clearly indicate the importance of selecting peach cultivars that produce EFN, and 


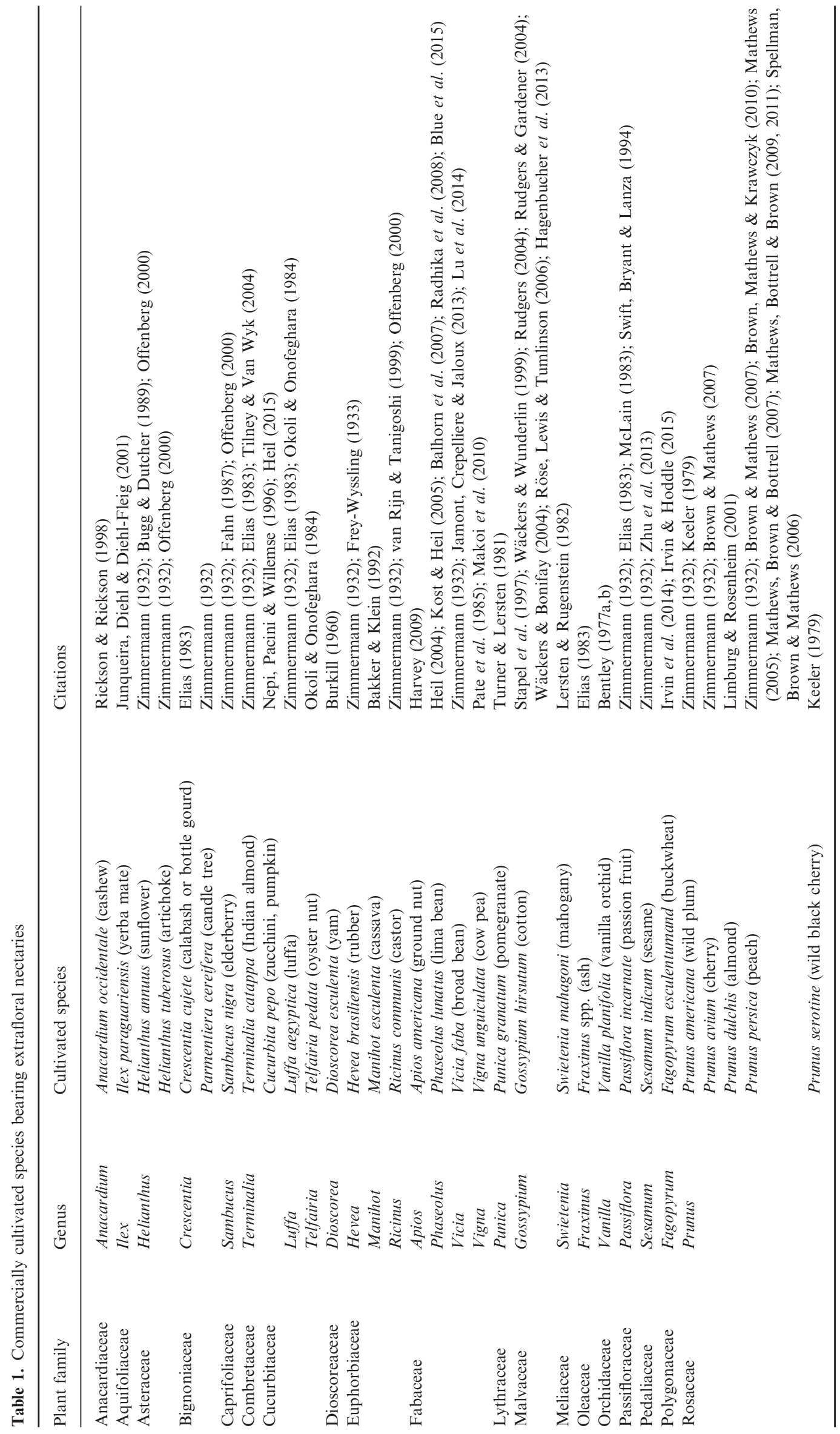


highlight the potential for peach production programmes to embrace biological control and reduce pesticide inputs. As peach is a grafted crop, EFNs could also be a target of stock selection. Peaches may represent a useful companion plant for other orchard crops. Several attempts have been made to utilize EFN-producing peaches to enhance biological control in apples, with varying degrees of success (Spellman, Brown \& Mathews 2006; Brown \& Mathews 2007; Brown, Mathews \& Krawczyk 2010). These studies show how difficult it is to identify the true effects of EFN on biological control, and highlight the need for more comprehensive long-term studies.

Spellman, Brown \& Mathews (2006) interplanted peaches with apples, in glasshouse conditions, with a view to enhancing the biological control of spiraea aphids, Aphis spiraecola. Contrary to expectations, aphid control on apples by the predatory beetle, Harmonia axyridis, was actually reduced in the presence of peaches. In this case, it seemed that EFN distracted the beetles from their aphid prey. Had the experiment taken place in field conditions, however, EFN may have attracted greater numbers of predators or helped to maintain predator populations during times of prey scarcity (Stapel et al. 1997). Extrafloral nectar may also have attracted predators to orchards before pests arrived therefore reducing defensive response time (Mathews 2005). None of these effects, however, could be captured in a short-term glasshouse study.

Brown, Mathews \& Krawczyk (2010) used EFN-producing peaches in apple orchards in an attempt to increase parasitism rates of the tufted apple bud moth, Platynota idaeusalis. Although the presence of peach trees did increase the number of parasitoids (Coniozus floridanus), parasitism rates were not significantly affected. Although control of the tufted apple bud moth was not achieved, damage to apple fruit, from a host of other herbivores, was reduced in the presence of interplanted peaches (Brown, Mathews \& Krawczyk 2010). In this study, the collection of data on variables beyond the target species facilitated the discovery of an important and unexpected result. This provides a valuable lesson for future research into the role of EFN in biological control: that the effects of EFN, as with any habitat manipulation, can only be understood in the context of the whole community.

Outside the Rosaceae, one orchard species that has received significant attention in terms of its EFN production is the cashew nut, Anacardium occidentale. Cashew trees produce EFN from their leaves, bracts, sepals and from stomata found on the inside curve of developing nuts (Rickson \& Rickson 1998). The plant has been described as providing a 'movable feast' for ants (Tilman 1978; Fiala \& Maschwitz 1992), shifting their foraging habits, temporally, towards sites most susceptible to herbivory. Interactions between cashew and weaver ants, Oecophylla spp, have been the focus of many studies, and the potential to harness these interactions for pest management has been explored over a large geographic range (Peng, Christian \& Gibb 1995; Dwomoh et al. 2009;
Olotu et al. 2013; Peng, Lan \& Christian 2014; Anato et al. 2015).

The presence of the weaver ant, Oecophylla smaragdina, has been correlated with a reduction in key pest species in Australian cashew plantings (Peng, Christian \& Gibb 1995). Peng, Lan \& Christian (2014) also manipulated weaver ants in cashew plantations in Vietnam. Damage from a range of important economic pests was reduced in the presence of ants, and in the case of mosquito bugs, blue shoot borers and fruit-nut borers, ants provided a level of control equivalent to that achieved through the use of insecticides. Anato et al. (2015) studied the effects of weaver ants in cashew plantations in Benin. Not only did the presence of ants increase nut yield, but the benefits of ants were enhanced through the provision of dietary subsidies ( $30 \%$ sucrose solution). Nut yields were highest of all when ants were incorporated into an integrated pest management programme that included spot spraying with insecticides (Anato et al. 2015).

The use of ants as agents of biological control in tree crops is by no means a new phenomenon. In Chinese citrus orchards, manipulations of Oecophylla ants have been common practice for 1500 years (Huang \& Yang 1987; Rickson \& Rickson 1998). The crazy ant, Anoplolepis gracilipes, has long been manipulated as a cacao pest control agent in Papua New Guinea (Baker 1972) and, in Cameroon, artificial raffia nests are used to transport Wasmannia auropuncta to cacao plantations for the control of several pest species (Bruneau De Mire 1969). Enormous potential exists to harness EFN-mediated interactions in a host of orchard crops and reduce or eliminate the use of expensive and environmentally damaging pesticides.

\section{Extrafloral nectar in herbaceous crops}

A host of herbaceous crop species from a diverse taxonomy are known to produce EFN. These include several species of huge commercial significance, such as pumpkin (Cucurbitaceae), zucchini (Cucurbitaceae) and yam (Dioscoreaceae), all of which have been little studied in the context of their EFN production (Burkill 1960; Nepi, Pacini \& Willemse 1996; Heil 2015). Several other species have received some attention in this regard, and some have demonstrated the potential to attract beneficial insects. Broad bean, Vicia faba, produces EFN from stipular glands, which has been observed to support the cosmopolitan aphid parasitoid, Diaeretiella rapae (Jamont, Crepelliere \& Jaloux 2013). Cassava, Manihot esculenta, produces EFN from its petioles which has been shown to enhance the activity of predatory phytoseiid mites (Bakker \& Klein 1992). Passion fruit, Passiflora incarnata, bears EFNs on its petioles and bracts, and these nectaries attract ants that discourage insect herbivores. McLain (1983) experimentally removed EFNs from passion fruit vines and found that nectariless plants suffered greater herbivore damage and produced fewer fruits. In passion 
fruit, as in many plants, EFN production is inducible by leaf damage (Swift, Bryant \& Lanza 1994). This means that plants are able to upregulate ant defence in response to herbivory (Koptur 1989; Agrawal \& Rutter 1998).

Although many other commercial crops are known to produce EFN (Table 1), few have been studied in this context. In this section, we focus on two important crop species on which the great majority of attention has focused. These species are cotton, Gossypium hirsutum (Malvaceae) (Stapel et al. 1997; Wäckers \& Wunderlin 1999; Rudgers 2004; Rudgers \& Gardener 2004; Wäckers \& Bonifay 2004; Röse, Lewis \& Tumlinson 2006; Hagenbucher et al. 2013), and lima bean, Phaseolus lunatus (Fabaceae) (Heil 2004; Kost \& Heil 2005; Balhorn et al. 2007; Radhika et al. 2008; Blue et al. 2015).

Cotton (Gossypium) represents one of the best-studied plants in terms of the ecology of its EFN and provides some of the best evidence that EFN evolved to attract defensive ants (Wäckers \& Bonifay 2004; Hagenbucher et al. 2013). Extrafloral nectar is found on all species of Gossypium with only two exceptions (Fryxell 1979). The first of these nectariless cotton species, Gossypium tomentosum, is endemic to Hawaii (Fryxell 1979), a part of the world with no native ants (Wilson 1996). The second species, Gossypium gossypioides, grows at high altitudes where ant activity is greatly limited (Wäckers \& Bonifay 2004). In species of cotton that produce EFN, its production has been shown to be inducible by both above- and below-ground herbivory (Wackers \& Bezemer 2003; Wäckers \& Bonifay 2004) and appears to be enhanced in the most valuable and vulnerable plant tissues as predicted by optimal defence theory (Wäckers \& Bonifay 2004).

In wild cotton, Gossypium thurberi, the presence of ants has been shown to reduce herbivory and increase seed production (Rudgers 2003). In addition to ants, assemblages of other beneficial insects have been found to be enhanced on cotton plants with EFNs (Schuster, Lukefahr \& Maxwell 1976; Henneberry, Bariola \& Kitoc 1977; Adjei-Maafo \& Wilson 1983; Adjei-Maafo et al. 1983). Stapel et al. (1997) and Röse, Lewis \& Tumlinson (2006) showed that the presence of EFN increased the efficiency of the parasitoid wasp, Microplitis croceipes, on Gossypium hirsutum. Other consumers of EFN, such as predatory mites, have also been observed to reduce herbivory in cotton (Agrawal, Karban \& Colfer 2000; Hagenbucher et al. 2013).

Despite abundant evidence that EFN is an effective plant defence in cotton, relatively few studies have focused on commercially cultivated species, in true agricultural settings. The few studies of this type have revealed a common ecological cost of EFN production. Herbivores, as well as beneficial insects, may utilize EFN as a food source. In agricultural settings, cotton cultivars bearing EFNs have been observed to support larger herbivore populations than cultivars that lack EFNs (Lukefahr \& Rhyne 1960; Lukefahr, Martin \& Meyer 1965;
Schuster, Lukefahr \& Maxwell 1976; Henneberry, Bariola \& Kitoc 1977; Adjei-Maafo \& Wilson 1983; Scott, Snodgrass \& Smith 1988). These findings contrast observations made in more natural settings (Rudgers 2003), but are not entirely surprising. In agricultural ecosystems, land management practices commonly reduce populations of ants and other beneficial insects. Any attempts to utilize EFN in agricultural pest management, therefore, must consider the effects of ecological context.

Perennial legumes have often been used in experimental systems to investigate the ecological role of EFN (e.g. Heil 2004; Choh, Kugimiya \& Takabayashi 2006; Jones \& Koptur 2015a,b; Koptur, Jones \& Pena 2015). These include widely cultivated crop species such as cowpea (black-eyed pea), Vigna unguiculata (Pate et al. 1985), and lima bean, Phaseolus lunatus (Heil 2004; Kost \& Heil 2005; Balhorn et al. 2007; Radhika et al. 2008; Blue et al. 2015). In lima bean, several studies support EFN as an effective inducible defence against herbivores (Heil 2004; Kost \& Heil 2005; Radhika et al. 2008). Kost \& Heil (2005) applied artificial nectar to lima bean plants and found that test plants attracted greater numbers of ants, predatory flies and parasitic wasps than untreated controls. Furthermore, treatment plants suffered reduced herbivore damage as a result. Heil (2004) found that EFN production in lima bean could be induced through application of the phytohormone jasmonic acid and that the induction of EFN resulted in lower herbivore damage in natural conditions.

Despite the obvious potential, no attempt has ever been made to harness or manipulate EFN in commercial cotton or lima bean production. This is particularly surprising in lima bean, where manipulation of EFN production has been shown to enhance plant defence (Heil 2004). Below, we explore the factors that have prevented our knowledge of EFN from being applied in agricultural pest management and discuss areas where these obstacles may be overcome.

\section{Obstacles for the use of EFN in agriculture}

The role of EFN in plant defence has long been understood and is supported by decades of literature (Heil 2015). Research into the biological control of agricultural pests has been ongoing throughout this time and, yet, startlingly little attention has been paid to the potential role of EFN. A host of factors may have contributed to this phenomenon.

A concern among plant physiologists may have been allocation costs associated with the production of EFN. Is it possible that increased EFN production might result in lower reproductive investment? Reproductive output, after all, is where the interests of most commercial growers lie. Additionally, do trade-offs exist between key plant defence traits? For example, is increased EFN production coupled with a reduction in chemical defences? The inducible nature of EFN itself implies that its production 
comes at a tangible metabolic cost (Heil \& Baldwin 2002), but existing estimates of these costs are low (O'Dowd 1980). O'Dowd (1980) quantified the costs of EFN and food body production in Ochroma pyramidale at around $1 \%$ of the investment in leaves. There is no evidence of trade-offs between EFN production and reproductive output; indeed, EFN production has often been observed to increase during flowering and fruit set (Holland, Chamberlain \& Horn 2009; Falcão, Dáttilo \& Izzo 2014). While trade-offs do exist between plant defensive traits (Koptur 1985; Turner 1995; Heil et al. 1999; Heil, Staehelin \& McKey 2000b; Dyer et al. 2001), the induction of EFN has never been associated with overall defensive cuts. Rudgers \& Gardener (2004) looked for trade-offs between resistance traits in wild cotton. Although they found negative correlations between direct plant resistance traits (leaf trichomes and toxic leaf glands), no correlation was found between EFN production and direct defensive traits. Future research should continue to explore potential allocation costs associated with EFN production. Current knowledge, however, suggests that these costs are minimal and should not impede the use of EFN in agriculture.

Despite the well-documented defensive benefits of EFN production, commercial breeders have often deliberately selected for nectariless cultivars, believing the attraction of insects to be detrimental (Beach, Todd \& Baker 1985). Breeding strategies have regularly failed to consider topdown control and, in many commercial crop lines, interactions with the third trophic level are impaired compared with their wild relatives (Heil 2015). Commercial cultivars of cotton, for example, produce less EFN (Beach, Todd \& Baker 1985) and release seven times less herbivoreinduced volatiles than naturalized lines (Loughrin et al. 1995). Breeding crops for increased EFN production, and an enhanced capacity to exploit beneficial insects, can contribute to environmentally friendly and sustainable agriculture, a concept explored in detail by Stenberg et al. (2015).

The tendency of breeders to ignore the tools of biological control are concerning in themselves, but they also point to a wider problem. Many growers, particularly large enterprises, set their pest control targets at a $100 \%$ reduction in infestation. Such targets can only be achieved through the use of pesticides and not through biological pest management programmes that seek to control, not eliminate, pest species. The use of broad-spectrum pesticides, and the harnessing of arthropod communities for pest control, are not strategies that can be easily married. Until growers relinquish their dependence on the former, little progress can be made on the latter.

As the examples above indicate, several of the perceived obstacles for the use of EFN in agriculture exist largely in the minds of breeders, and in the culture of commercial farming. There remain, however, genuine costs of EFN production, and grower concerns about its negative impacts are not entirely without foundation. In the absence of viable ant partners, EFNs are open to exploitation by a host of other arthropods, many of which may have neutral or negative effects on plant fitness (Koptur 1992a; Heil et al. 2004b). Ants, themselves, vary in their defensive qualities. Production of EFN can result in colonization by parasitic ant species which consume nectar but either fail to defend their host plants or actively harm them (Koptur 1992b; Yu \& Pierce 1998). Ants that benefit EFN-producing plants must occupy a trophic position whereby they are attracted to EFN, but act predominantly as predators while on the plant. The trophic position and foraging behaviour of ants, however, can vary enormously even within a single species. The degree to which ants act as predators or feed on plantderived carbohydrates can vary over the life of a colony and can be influenced by ecological conditions (Wilder et al. 2011). Even voraciously defensive ants may negatively impact plant fitness by deterring other beneficial insects such as predators (Torres-Hernandez et al. 2000; Nahas, Gonzaga \& Del-Claro 2012), parasitoids (Koptur \& Lawton 1988; Styrsky \& Eubanks 2007; Rosumek et al. 2009) and pollinators (Ness 2006; Hernández-Cumplido, Benrey \& Heil 2010; Assunção, Torezan-Silingardi \& DelClaro 2014).

Among the non-target species subjected to attacks by defensive ants are humans. Many growers are reluctant to encourage the presence of aggressive ants, as their bites and stings represent a potential irritant for farm workers and animals (Risch \& Carroll 1982; Offenberg 2015). While the nuisance value of ants can be a significant issue, a number of methods have been adopted to successfully ameliorate this problem. For example, applying fine powders, such as wood ash or cassava flour, to exposed skin has been shown to reduce bites from weaver ants (Van Mele et al. 2009). Spraying crops with water can also inactivate ants for short periods and provide a window for harvesting (Offenberg 2015). The dissemination of ecological knowledge, about the benefits of ants, will also increase tolerance among stakeholders.

Ecological costs of EFN production, like those described above, may be a major problem in agricultural ecosystems, which rarely provide stable populations of beneficial insects (Adjei-Maafo \& Wilson 1983; Heil 2015). Abiotic factors such as light (Kersch \& Fonseca 2005; Jones \& Koptur 2015b) or nutrient (Heil et al. 2001b) availability are also known to affect EFN production and influence its effectiveness as a plant defence. The outcomes of EFN-mediated interactions, therefore, are greatly influenced by ecological context. This, without doubt, represents the most significant obstacle for the use of EFN in agricultural pest management.

\section{Overcoming context dependence}

For any attempt to utilize EFN in agricultural pest management, the chances of success are strongly dependent on ecological context. Improving those chances, therefore, can be achieved in one of two ways. Manipulating the 
habitat in favour of beneficial insects or selecting agricultural systems that naturally support diverse arthropod populations.

Most contemporary farming landscapes are characterized by high levels of disturbance, intensive use of pesticides and a reduction in non-crop habitats. These factors bring about a sharp decline in biodiversity and, in turn, the biological control service provided by arthropod natural enemies (Lu et al. 2014). The potential to enhance the activity of natural enemies by manipulating the non-crop vegetation on or close to farms has been well-established (Tscharntke et al. 2007; Thomson et al. 2010; Simpson et al. 2011; Orre-Gordon et al. 2013). This form of biological control has been formalized as the 'attract and reward' concept (Simpson et al. 2011), and the use of EFN-producing plants for this purpose may be particularly beneficial. In many ecosystems, EFN may be a more important source of sugar than floral nectar, as it is available over longer periods (Heil et al. 2004b; Géneau et al. 2012), and may contain fewer defensive compounds (Lu et al. 2014).

In California vineyards, the glassywinged sharpshooter, Homalodisca vitripennis, is a significant pest on grapevines as it vectors the bacterial disease, Xylella fastidiosa. Irvin et al. (2014) conducted laboratory tests to evaluate the potential of EFN-producing cover crops, to increase parasitization of $H$. vitripennis by the chalcid wasp, Gonatocerus ashmeadi. Extrafloral nectar from buckwheat, Fagopyrum esculentum, and vetch, Vicia sativa, extended the life span of $G$. ashmeadi and enhanced its reproductive fitness. Nectar from buckwheat and vetch also increased the life span of Anagyrus pseudococci, a parasitoid of the vine mealybug (Irvin et al. 2014).

Several other EFN-producing plants show great potential for supporting natural enemies in agricultural habitats. Géneau et al. (2012) tested Centaurea cyanus and Vicia sativa as companion plants for cabbage. Both plants increased the longevity of the parasitoid wasp, Microplitis mediator, and enhanced parasitization rates of the cabbage moth Mamestra brassicae. Sesame, Sesamum indicum, has also shown potential, in the laboratory, as a nectar plant to enhance biological control in Asian rice systems (Zhu et al. 2013). Another focus for future research in this area should be faba bean, Vicia faba, which produces nectaries on its stipules well before the emergence of flowers (Lu et al. 2014). This early provision of nectar could attract natural enemies very early in the growing season and potentially stunt early season pest population growth.

In addition to providing resources for natural enemies, arthropod assemblages may also be manipulated through the active release of beneficial insects. While established practice in many biological control programmes, active release has never been done specifically with EFN in mind. The potential of ants, the primary consumers of EFN, as biological control agents, however, has received greater attention in recent years (Peng, Christian \& Gibb
1995; Peng \& Christian 2005; Philpott \& Foster 2005; Peng, Christian \& Reilly 2010, 2013; Offenberg 2015). Introducing weaver ants, Oecophylla smaragdina, to mahogany plantations led to significant reductions in damage by the yellow looper, Gymnoscelis sp., and the bush cricket, Myara yabmanna (Peng, Christian \& Reilly 2013). Providing ants with artificial nesting space has also been shown to enhance predation pressure on pests of coffee, Coffea arabica (Philpott \& Foster 2005).

Habitat manipulations, like those described above, are an option in the majority of modern agricultural systems, which lack habitat heterogeneity and rely heavily on chemical insecticides. Agricultural practices do exist, however, that actively promote habitat diversity and sustain complex insect assemblages. On the slopes of Mount Kilimanjaro are the Chagga homegardens, a traditional agroforestry system that combines subsistence and commercial farming and makes use of limited space. These multilayered systems are predominantly banana and coffee plantations, with a scattered upper tree layer, but they contain a huge diversity of plants (about 520 vascular plant species including over 400 non-cultivated species) and support a higher diversity of insects than neighbouring habitats (Hemp 2006). A native Cucurbitaceae, Telphairia pedata, is an important subsistence crop in these systems (Hemp 2006) and produces EFN from its stipules (Bosa \& Mgbeogu 1983). Commercial crop species with EFNs (Casava, Manihot esculenta, and black-eyed pea, Vigna unguiculata) are also cultivated locally (Hemp 2006; Makoi et al. 2010).

Semicultivated ecosystems, such as the Chagga homegardens, may be ideal systems in which to focus future research. Selecting for EFN-producing crop cultivars, introducing defensive ant species, and disseminating local knowledge could be useful tools for harnessing EFN in sustainable biological control programmes with tangible benefits for local people.

\section{Conclusions}

Ants, the primary consumers of EFN, have unrivalled potential as agents of biological pest control. Predatory ants tend to have relatively non-specialized diets, making them resilient to periods of prey scarcity (Carroll \& Janzen 1973). Sophisticated systems of chemical communication and recruitment make ants highly responsive to spatial variations in prey density, where non-social predators and parasitoids require reproductive time for density response (Risch \& Carroll 1982). Because ants store food for their colony, their effectiveness as control agents is not dampened by satiation, and their pugnacious nature means that their deterrence of pests is not limited to prey species. Several studies have observed ants to deter herbivores too large to be captured (Janzen 1966; Bentley 1977a,b). Many ant species are extremely resistant to environmental disturbance. Solenopsis species, for example, although unpopular, often thrive in ploughed crop fields 
and are known to control a variety of important pests (Summerlin et al. 1977; Morrill 1978; Sterling 1978; Risch \& Carroll 1982). Perhaps, most importantly, patterns of ant foraging behaviour can be manipulated, through the provision of resources such as EFN, in order to maximize the rate at which they encounter pests (Leston 1973).

We have emphasized that the potential exists to utilize EFN as a resource for crop protection in many agricultural ecosystems. Though we have stressed the importance of ecological context, and the lack of any one-size-fits-all solution, recent reviews have highlighted an overriding trend. In the great majority of cases, ants benefit plants, either a little bit or a lot (Chamberlain \& Holland 2009; Rosumek et al. 2009). Extrafloral nectar has also shown great potential for enhancing the performance of parasitoids (e.g. Irvin et al. 2014; Jamont, Dubois-Pot \& Jaloux 2014; Irvin \& Hoddle 2015). While the role of EFN in attracting and supporting parasitoids has been well-established (Heil 2015), few studies have demonstrated beneficial effects of parasitoids on plant reproductive fitness. This represents a timely and a potentially fruitful avenue for future research. Also deserving of increased attention is the way that parasitoids use EFN. Do they use it only as a food source, or can it serve as a cue for host location?

In a world of diminishing resources, it is time to work with nature, and shift our focus from simply understanding insect-plant symbioses to harnessing their potential to provide effective and low cost options for pest control. There exists huge potential to utilize EFN-mediated interactions in a range of agricultural settings to maximize crop plant success while minimizing environmental impacts.

\section{Data accessibility}

Data have not been archived because this article does not contain data.

\section{References}

Adjei-Maafo, K. \& Wilson, L.T. (1983) Factors affecting the relative abundance of arthropods on nectaried and nectariless cotton. Environmental Entomology, 12, 349-352.

Adjei-maafo, I.K., Wilson, L.T., Thompson, N.J. \& Blood, P.R.B. (1983) Effect of pest damage intensity on the growth, maturation, and yield of nectaried and nectariless cotton. Environmental Entomology, 12, 353 358

Agrawal, A.A., Karban, R. \& Colfer, R.G. (2000) How leaf domatia and induced plant resistance affect herbivores, natural enemies and plant performance. Oikos, 89, 70-80.

Agrawal, A.A. \& Rutter, M.T. (1998) Dynamic anti-herbivore defense in ant-plants: the role of induced responses. Oikos, 83, 227-236.

Anato, F.M., Wargui, R., Sinzogan, A., Offenberg, J., Adandonon, A., Vayssieres, J.F. \& Kossou, D.K. (2015) Reducing losses inflicted by insect pests on cashew, using weaver ants as efficient biological control agent. Agricultural and Forest Entomology, 17, 285-291.

Assunção, M.A., Torezan-Silingardi, H.M. \& Del-Claro, K. (2014) Do ant visitors to extrafloral nectaries of plants repel pollinators and cause an indirect cost of mutualism? Flora-Morphology, Distribution, Functional Ecology of Plants, 209, 244-249.

Baker, G. (1972) The role of Anoplolepis longipes Jerdon (Hymenoptera: Formicidae) in the entomology of cacao in the Northern District of
Papua New Guinea. In International Congress of Entomology, Abstracts, 327. Canberra, Australia.

Baker, D.A., Hall, L.J. \& Thorpe, J.R. (1978) A study of the extrafloral nectaries of Ricinus communis. New Phytologist, 81, 129-137.

Bakker, F.M. \& Klein, M.E. (1992) How cassava plants enhance the efficacy of their phytoseiid bodyguards. Series Entomologica (Dordrecht), 49, 353-354

Balhorn, D.J., Pietrowski, A., Heil, M. \& Lieberei, R. (2007) Quantitative effects of cyanogenesis on an adapted herbivore. Journal of Chemical Ecology, 33, 2195-2208.

Beach, R.M., Todd, J.W. \& Baker, S.H. (1985) Nectaried and nectariless cotton cultivars as nectar sources for the adult soybean looper. Journal of Entomological Science, 20, 233-236.

Becerra, J.X.I. \& Venable, D.L. (1989) Extrafloral nectaries: a defence against ant-homoptera mutualisms? Oikos, 55, 276-280.

Belt, T. (1874) The Naturalist in Nicaragua. J. Murray, London, UK.

Bentley, B.L. (1977a) The protective function of ants visiting the extrafloral nectaries of Bixa orellana (Bixaceae). Journal of Ecology, 65, 27.

Bentley, B.L. (1977b) Extrafloral nectaries and protection by pugnacious bodyguards. Annual Review of Ecology and Systematics, 8, 407-427.

Blue, E., Kay, J., Younginger, B.S. \& Ballhorn, D.J. (2015) Differential effects of type and quantity of leaf damage on growth, reproduction and defence of lima bean (Phaseolus lunatus L.). Plant Biology, 17, 712-719.

Boege, K. \& Marquis, R.J. (2005) Facing herbivory as you grow up: the ontogeny of resistance in plants. Trends in Ecology and Evolution, 20, 441-448.

Bosa, E.O. \& Mgbeogu, C.M. (1983) Fluted pumpkin, Telfairia occidentafis: West African vegetable crop. Economic Botany, 37, 145-149.

Brown, M.W. \& Mathews, C.R. (2007) Conservation biological control of rosy apple aphid, Dysaphis plantaginea (Passerini), in Eastern North America. Environmental Entomology, 36, 1131-1139.

Brown, M.W., Mathews, C.R. \& Krawczyk, G. (2010) Extrafloral nectar in an apple ecosystem to enhance biological control. Journal of Economic Entomology, 103, 1657-1664.

Bruneau De Mire, P. (1969) Une fourmi utilisee au Cameroun dans la lutte contre les mirides du cacaoyer Wasmannia auropunctata Roger. The Cafe Cacao, 8, 209-212.

Bugg, R.L. \& Dutcher, J.D. (1989) Warm-season cover crops for pecan orchards: horticultural and entomological implications. Biological Agriculture \& Horticulture, 6, 123-148.

Bugg, R.L., Dutcher, J.D. \& McNeil, P.J. (1991) Cool-season cover crops in the pecan orchard understory: effects on Coccinellidae (Coleoptera) and pecan aphids (Homoptera: Aphididae). Biological Control, 1, 8-15.

Burkill, I.H. (1960) The organography and the evolution of Dioscoreaceae, the family of the yams. Botanical Journal of the Linnean Society, 56, $367-412$

Carroll, C.R. \& Janzen, D.H. (1973) Ecology of foraging by ants. Annual Review of Ecology and Systematics, 4, 231-251.

Chamberlain, S.A. \& Holland, J.N. (2009) Quantitative synthesis of context dependency in ant-plant protection mutualisms. Ecology, 90, 23842392.

Choh, Y., Kugimiya, S. \& Takabayashi, J. (2006) Induced production of extrafloral nectar in intact Lima bean plants in response to volatiles from spider mite-infested conspecific plants as a possible indirect defence against spider mites. Oecologia, 147, 455-460.

Dwomoh, E.A., Afun, J.V.K., Ackonor, J.B. \& Agene, V.N. (2009) Investigations on Oecophylla longinoda (Latreille) (Hymenoptera: Formicidae) as a biocontrol agent in the protection of cashew plantations. Pest Management Science, 65, 41-46.

Dyer, L.A., Dodson, C.D., Beihoffer, J. \& Letourneau, D.K. (2001) Trade-offs in antiherbivore defenses in Piper cenocladum: ant mutualists versus plant secondary metabolites. Journal of Chemical Ecology, 27, 581-592.

Elias, T.S. (1983) Extrafloral nectaries: their structure and distribution. The Biology of Nectaries (eds T.S. Elias \& B.L. Bentley), pp. 174-213. Columbia University Press, New York, NY, USA.

Fahn, A. (1987) The extrafloral nectaries of Sambucus nigra. Annals of Botany (London), 60, 299-308.

Falcão, J.C.F., Dáttilo, W. \& Izzo, T.J. (2014) Temporal variation in extrafloral nectar secretion in different ontogenic stages of the fruits of Alibertia verrucosa S. Moore (Rubiaceae) in a Neotropical savanna. Journal of Plant Interactions, 9, 137-142.

Fiala, B. \& Maschwitz, U. (1992) Food bodies and their significance for obligate ant-association in the tree genus Macaranga (Euphorbiaceae). Botanical Journal of the Linnean Society (London), 110, 61-75. 
Frey-Wyssling, A. (1933) Über die extrafloralen Nektarien von Hevea brasiliensis Mull. Berichte-Schweizerische Botanische Gesellschaft, 42, 109-122.

Fryxell, P.A. (1979) Natural History of the Cotton Tribe. Texas A\&M University Press, Colleges Station, TX, USA.

Géneau, C.E., Wäckers, F.L., Luka, H., Daniel, C. \& Balmer, O. (2012) Selective flowers to enhance biological control of cabbage pests by parasitoids. Basic and Applied Ecology, 13, 85-93.

Hagenbucher, S., Olson, D.M., Ruberson, J.R., Wäckers, F.L. \& Romeis, J. (2013) Resistance mechanisms against arthropod herbivores in cotton and their interactions with natural enemies. Critical Reviews in Plant Sciences, 32, 458-482.

Harvey, A. (2009) Extrafloral nectaries of kudzu Pueraria montana (Lour.) Merr., and groundnut Apios americana Medicus (Fabaceae). Castanea, 74, 360-371.

Heil, M. (2004) Induction of two indirect defences benefits Lima bean (Phaseolus lunatus, Fabaceae) in nature. Journal of Ecology, 92, 527536.

Heil, M. (2010) Plastic defense expression in plants. Evolutionary Ecology, 24, 555-569.

Heil, M. (2011) Nectar: generation, regulation and ecological functions. Trends in Plant Science, 16, 191-200.

Heil, M. (2015) Extrafloral nectar at the plant-insect interface: a spotlight on chemical ecology, phenotypic plasticity, and food webs. Аппиаl Review of Entomology, 60, 213-232.

Heil, M. \& Baldwin, I.T. (2002) Fitness costs of induced resistance: emerging experimental support for a slippery concept. Trends in Plant Science, 7, 61-67.

Heil, M., Staehelin, C. \& McKey, D. (2000b) Low chitinase activity in Acacia myrmecophytes: a potential trade-off between biotic and chemical defences? Naturwissenschaften, 87, 555-558.

Heil, M., Fiala, B., Linsenmair, K.E. \& Boller, T. (1999) Reduced chitinase activities in ant plants of the genus Macaranga. Naturvissenschaften, 86, 146-149.

Heil, M., Fiala, B., Baumann, B. \& Linsenmair, K.E. (2000a) Temporal, spatial and biotic variations in extrafloral nectar secretion by Macaranga tanarius. Functional Ecology, 14, 749-757.

Heil, M., Koch, T., Hilpert, A., Fiala, B., Boland, W. \& Linsenmair, K.E. (2001a) Extrafloral nectar production of the ant-associated plant, Macaranga tanarius, is an induced, indirect, defensive response elicited by jasmonic acid. Proceedings of the National Academy of Sciences of the United States of America, 98, 1083-1088.

Heil, M. Hilpert, A., Fiala, B. \& Linsenmair, K.E. (2001b) Nutrient availability and indirect (biotic) defence in a Malaysian ant-plant. Oecologia, 126, 404-408.

Heil, M., Feil, D., Hilpert, A. \& Linsenmair, K.E. (2004a) Spatiotemporal patterns in indirect defense of a South-East Asian and-plant support the optimal defense hypothesis. Journal of Tropical Ecology, 20, 573-580.

Heil, M., Hilpert, A., Kruger, R. \& Linsenmair, K.E. (2004b) Competition among visitors to extrafloral nectaries as a source of ecological costs of an indirect defence. Journal of Tropical Ecology, 20, 201-208.

Hemp, A. (2006) The banana forests of Kilimanjaro: biodiversity and conservation of the Chagga homegardens. Biodiversity and Conservation, $15,1193-1217$

Henneberry, T.J., Bariola, A. \& Kitoc, D.L. (1977) Nectariless cotton: effect on cotton leaf perforator and other cotton insects in Arizona. Journal of Economic Entomology, 70, 797-799.

Hernández-Cumplido, J., Benrey, B. \& Heil, M. (2010) Attraction of flower visitors to plants that express indirect defence can minimize ecological costs of ant-pollinator conflicts. Journal of Tropical Ecology, 26, $555-577$.

Holland, J.N., Chamberlain, A.A. \& Horn, K.C. (2009) Optimal defence theory predicts investment in extrafloral nectar resources in an ant-plant mutualism. Journal of Ecology, 97, 89-96.

Huang, H.T. \& Yang, P. (1987) The ancient cultured citrus ant. BioScience, 37, 665-671.

Irvin, N.A. \& Hoddle, M.S. (2015) The effect of buckwheat flowers and Cahaba vetch extrafloral nectaries on fitness of the vine mealybug parasitoid Anagyrus pseudococci (Hymenotpera: Encyrtidae). Florida Entomologist, 1, 237-242.

Irvin, N.A., Pinckard, T.R., Perring, T.M. \& Hoddle, M.S. (2014) Evaluating the potential of buckwheat and Cahaba vetch as nectar producing cover crops for enhancing biological control of Homalodisca vitripennis in California vineyards. Biological Control, 76, 10-18.
Jamont, M., Crepelliere, S. \& Jaloux, B. (2013) Effect of extrafloral nectar provisioning on the performance of the adult parasitoid Diaeretiella rapae. Biological Control, 65, 271-277.

Jamont, M., Dubois-Pot, C. \& Jaloux, B. (2014) Nectar provisioning close to host patches increases parasitoid recruitment, retention and host parasitism. Basic Applied Ecology, 15, 151-160.

Janzen, D.H. (1966) Coevolution of mutualism between ants and acacias in Central America. Evolution, 20, 249-275.

Jones, I.M. \& Koptur, S. (2015a) Dynamic extrafloral nectar production: the timing of leaf damage affects the defensive response in Senna mexicana var. chapmanii (Fabaceae). American Journal of Botany, 102, 58-66.

Jones, I.M. \& Koptur, S. (2015b) Quantity over quality: light intensity, but not red/far-red ratio, affects extrafloral nectar production in Senna mexicana var. chapmanii. Ecology and Evolution, 5, 4108-4114.

Junqueira, L.K., Diehl, E. \& Diehl-Fleig, E. (2001) Formigas (Hymenoptera: Formicidae) visitantes de Ilex paraguariensis (Aquifoliaceae). Neotropical Entomology, Piracicaba, 30, 161-164.

Keeler, K.H. (1979) Species with extrafloral nectaries in a temperate flora (Nebraska). Prairie Naturalist, 11, 33-38.

Kersch, M.F. \& Fonseca, C.R. (2005) Abiotic factors and the conditional outcome of an ant-plant mutualism. Ecology, 86, 2117-2126.

Koptur, S. (1979) Facultative mutualism between weedy vetches bearing extrafloral nectaries and weedy ants in California. American Journal of Botany, 66, 1016-1020.

Koptur, S. (1985) Alternative defenses against herbivores in Inga (Fabaceae: Mimosoideae) over an elevational gradient. Ecology, 66, 16391650 .

Koptur, S. (1989) Is extrafloral nectar production an inducible defence? Evolutionary Ecology of Plants (eds J. Bock \& Y. Linhart), pp. 323-339. Westview Press, Boulder, CO, USA.

Koptur, S. (1992a) Extrafloral nectary-mediated interactions between insects and plants. Insect-Plant Interactions. Vol. IV (ed. E.A. Bernays), pp. 81-129. CRC Press, Boca Raton, FL, USA.

Koptur, S. (1992b) Plants with extrafloral nectaries and ants in Everglades habitats. The Florida Entomologist, 75, 38-50.

Koptur, S., Jones, I.M. \& Pena, J.E. (2015) The influence of host plant extrafloral nectaries on multitrophic interactions: an experimental investigation. PLoS One, 10, e 0138157.

Koptur, S. \& Lawton, J.H. (1988) Interactions among vetches bearing extrafloral nectaries, their biotic protective agents, and herbivores. Ecology, 69, 278-283.

Koptur, S., Palacios-Rios, M., Diaz-Castelazo, C., Mackay, W.P. \& RicoGray, V. (2013) Nectar secretion on fern fronds associated with lower levels of herbivore damage: field experiments with a widespread epiphyte of Mexican cloud forest remnants. Annals of Botany, 111, 12771283

Kost, C. \& Heil, M. (2005) Increased availability of extrafloral nectar reduces herbivory in lima bean plants (Phaseolus lunatus, Fabaceae). Basic Applied Ecology, 6, 237-248.

Kwok, K.E. \& Laird, R.A. (2012) Plant age and the inducibility of extrafloral nectaries in Vicia faba. Plant Ecology, 213, 1823-1832.

Leal, I.R., Fischer, E., Kost, C., Tabarelli, M. \& Wirth, R. (2006) Ant protection against herbivores and nectar thieves in Passiflora coccinea flowers. Ecoscience, 13, 431-438.

Lersten, N.R. \& Rugenstein, S.R. (1982) Foliar nectaries in mahogany (Swietenia Jacq.). Annals of Botany, 49, 397-401.

Leston, D. (1973) The ant mosaic-tropical tree crops and the limiting of pests and diseases. Pest Articles and News Summaries, 19, 311-341.

Limburg, D.D. \& Rosenheim, J.A. (2001) Extrafloral nectar consumption and its influence on survival and development of an omnivorous predator, larval Chrysoperla plorabunda (Neuroptera: Chrysopidae). Environmental Entomology, 30, 595-604.

Loughrin, J., Manukian, A., Heath, R. \& Tumlinson, J. (1995) Volatiles emitted by different cotton varieties damaged by feeding beet armyworm larvae. Journal of Chemical Ecology, 21, 1217-1227.

Lu, Z.X., Zhu, P.Y., Gurr, G.M., Zheng, X.S., Read, D.M.Y., Heong, K.L. \& Xu, H.X. (2014) Mechanisms for flowering plants to benefit arthropod natural enemies of insect pests: prospects for enhanced use in agriculture. Insect Science, 21, 1-12.

Lukefahr, M.J., Martin, D.F. \& Meyer, J.R. (1965) Plant resistance to five Lepidoptera attacking cotton. Journal of Economic Entomology, 58, $516-518$

Lukefahr, M.L. \& Rhyne, C. (1960) Effects of nectariless cottons on populations of three lepidopterous insects. Journal of Economic Entomology, 53, $242-244$. 
Makoi, J.H., Belane, A.K., Chimphango, S. \& Dakora, F.D. (2010) Seed flavonoids and anthocyanins as markers of enhanced plant defence in nodulated cowpea (Vigna unguiculata L.Walp.). Field Crop Research, 118, 21-27.

Marazzi, B., Bronstein, J.L. \& Koptur, S. (2013) The diversity, ecology and evolution of extrafloral nectaries: current perspectives and future challenges. Annals of Botany, 111, 1243-1250.

Mathews, C.R. (2005) Role of peach [Prunus persica (L.) Batsch] extrafloral nectaries in mediating natural enemy-herbivore interactions. $\mathrm{PhD}$ dissertation. University of Maryland, College Park, MD, USA.

Mathews, C.R., Bottrell, D.G. \& Brown, M.W. (2009) Extrafloral nectaries alter arthropod community structure and mediate peach (Prunus persica) plant defense. Ecological Applications, 19, 722-730.

Mathews, C.R., Bottrell, D.G. \& Brown, M.W. (2011) Interactions between extrafloral nectaries, ants (Hymenoptera: Formicidae), and other natural enemies affect biological control of Grapholita molesta (Lepidoptera: Tortricidae) on peach (Rosales: Rosaceae). Environmental Entomology, 40, 42-51.

Mathews, C.R., Brown, M.W. \& Bottrell, D.G. (2007) Leaf extrafloral nectaries enhance biological control of a key economic pest, Grapholita molesta (Lepidoptera: Tortricidae), in peach (Rosales: Rosaceae). Environmental Entomology, 36, 383-389.

McKey, D. (1974) Adaptive patterns in alkaloid physiology. American Naturalist, 108, 305-320.

McLain, D.K. (1983) Ants, extrafloral nectaries and herbivory on the passion vine, Passiflora incarnata. American Midland Naturalist, 110, 433-439.

Mondor, E.B. \& Addicott, J.F. (2003) Conspicuous extra-floral nectaries are inducible in Vicia faba. Ecology Letters, 6, 495-497.

Morrill, W.L. (1978) Red imported fire ant predation on the alfalfa weevil and pea aphid. Journal of Economic Entomology, 71, 867-868.

Nahas, L., Gonzaga, M.O. \& Del-Claro, K. (2012) Emergent impacts of ant and spider interactions: herbivory reduction in a tropical savanna tree. Biotropica, 44, 498-505.

Nepi, M., Pacini, E. \& Willemse, M.T.M. (1996) Nectary biology of Cucurbita pepo: ecophysiological aspects. Acta Botanica Neerlandica, $\mathbf{4 5}$ 41-45.

Ness, J.H. (2006) A mutualism's indirect costs: the most aggressive plan bodyguards also deter pollinators. Oikos, 113, 506-514.

O'Dowd, D.J. (1980) Pearl bodies of a neotropical tree, Ochroma pyramidale: ecological implications. American Journal of Botany, 67, 543-549.

Offenberg, J. (2000) Correlated evolution of the association between aphids and ants and the association between aphids and plants with extrafloral nectaries. Oikos, 91, 146-152.

Offenberg, J. (2015) Ants as tools in sustainable agriculture: the case of weaver ants and beyond. Journal of Applied Ecology, 52, 1197-1205.

Okoli, B.E. \& Onofeghara, F.A. (1984) Distribution and morphology of extrafloral nectaries in some Cucurbitaceae. Botanical Journal of the Linnean Society, 89, 153-164.

Oliveira, P.S. (1997) The ecological function of extrafloral nectaries: herbivore deterrence by visiting ants and reproductive output in Caryocar brasiliense (Caryocaraceae). Functional Ecology, 11, 323-330.

Olotu, M.I., Plessis, H., Seguni, Z. \& Maniania, N.K. (2013) Efficacy of the African weaver ant Oecophylla longinoda (Hymenoptera: Formicidae) in the control of Helopeltis spp. (Hemiptera: Miridae) and Pseudotheraptus wayi (Hemiptera: Coreidae) in cashew crop in Tanzania Pest Management Science, 69, 911-918.

Orre-Gordon, G.U.S., Wratten, S.D., Jonsson, M., Simpson, M. \& Hale, R. (2013) 'Attract and reward': combining a herbivore-induced plant volatile with floral resource supplementation - multi-trophic level effects. Biological Control, 64, 106-115.

Pate, J.S., Peoples, M.B., Storer, P.J. \& Atkins, C.A. (1985) The extrafloral nectaries of cowpea (Vigna unguiculata (L.) Walp.) II. Nectar composition, origin of nectar solutes, and nectary functioning. Planta, 166, 28-38.

Peng, R.K. \& Christian, K. (2005) Integrated pest management in mango orchards in the Northern Territory of Australia using the weaver ant, Oecophylla smaragdina, (Hymenoptera: Formicidae) as a key element. International Journal of Pest Management, 51, 149-155.

Peng, R.K., Christian, K. \& Gibb, K. (1995) The effect of the green ant, Oecophylla smaragdina (Hymenoptera: Formicidae), on insect pests of cashew trees in Australia. Bulletin of Entomological Research, 85, 279284.

Peng, R.K., Christian, K. \& Reilly, D. (2010) Weaver ants, Oecophylla smaragdina (Hymenoptera: Formicidae), as bio-control agents on African mahogany trees, Khaya senegalensis (Sapindales: Meliaceae), in the
Northern Territory of Australia. International Journal of Pest Management, 56, 363-370.

Peng, R.K., Christian, K. \& Reilly, D. (2013) Using weaver ants, Oecophylla smaragdina, to control two important pests on African Mahogany, Khaya senegalensis, in the Northern Territory of Australia. Australian Forestry, 76, 76-82.

Peng, R.K., Lan, L.P. \& Christian, K. (2014) Weaver ant role in cashew orchards in Vietnam. Journal of Economic Entomology, 107, 1330-1338.

Philpott, S.M. \& Foster, P.F. (2005) Nest-site limitation in coffee agroecosystems: artificial nests maintain diversity of arboreal ants. Ecological Applications, 15, 1478-1485.

Quintero, C., Barton, K.E. \& Boege, K. (2013) The ontogeny of plant indirect defences. Perspectives in Plant Ecology, Evolution and Systematics, 15, 245-254.

Radhika, V., Kost, C., Bartram, S., Heil, M. \& Boland, W. (2008) Testing the optimal defence hypothesis for two indirect defences: extrafloral nectar and volatile organic compounds. Planta, 228, 449-457.

Rickson, F.R. \& Rickson, M.M. (1998) The cashew nut, Anacardium occidentale (Anacardiaceae), and its perennial association with ants: extrafloral nectary location and the potential for ant defense. American Journal of Botany, 85, 835-849.

van Rijn, P.C.J. \& Tanigoshi, L.K. (1999) The contribution of extrafloral nectar to survival and reproduction of the predatory mite Iphiseius degenerans on Ricinus communis. Experimental and Applied Acarology, 23, 281-296.

Risch, S.J. \& Carroll, C.R. (1982) The ecological role of ants in two Mexican agroecosystems. Oecologia, 55, 114-119

Röse, U.S.R., Lewis, J. \& Tumlinson, J.H. (2006) Extrafloral nectar from cotton (Gossypium hirsutum) as a food source for parasitic wasps. Functional Ecology, 20, 67-74.

Rosumek, F.B., Silveira, F.A.O., Neves, F.D., Barbosa, N.P.D., Diniz, L., Oki, Y., Pezzini, F., Fernandes, G.W. \& Cornelissen, T. (2009) Ants on plants: a meta-analysis of the role of ants as plant biotic defenses. Oecologia, 160, 537-549.

Rudgers, J.A. (2003) Behavioral mechanisms underlie an ant-plant mutualism. Oecologia, 135, 51-59.

Rudgers, J.A. (2004) Enemies of herbivores can shape plant traits: selection in a facultative ant-plant mutualism. Ecology, 85, 192-205.

Rudgers, J. \& Gardener, M.C. (2004) Extrafloral nectar as a resource mediating multispecies interactions. Ecology, 85, 1495-1502.

Schuster, M.F., Lukefahr, M.J. \& Maxwell, F.G. (1976) Impact of nectariless cotton on plant bugs and natural enemies. Journal of Economic Entomology, 69, 400-402.

Scott, W.P., Snodgrass, G.L. \& Smith, J.W. (1988) Tarnished plant bug (Hemiptera, Miridae) and predaceous arthropod populations in commercially produced selected nectaried and nectariless cultivars of cotton. Journal of Entomological Science, 23, 280-286.

Simpson, M., Gurr, G.M., Simmons, A.T., Wratten, S.D., James, D.G., Leeson, G., Nicol, H.I. \& Orre, G.U.S. (2011) Field evaluation of the 'attract and reward' biological control approach in vineyards. Annals of Applied Biology, 159, 69-78.

Spellman, B., Brown, M.W. \& Mathews, C.R. (2006) Effect of floral and extrafloral resources on predation of Aphis spiraecola by Harmonia axyridis on apple. BioControl, 51, 715-724.

Stapel, J.O., Cortesero, A.M., de Moraes, C.M., Tumlinson, J.H. \& Lewis, W.J. (1997) Extrafloral nectar, honeydew, and sucrose effects on searching behavior and efficiency of Microplitis croceipes (Hymenoptera: Braconidae) in cotton. Environmental Entomology, 26, 617-623.

Stenberg, J.A., Heil, M., Åhman, I. \& Björkman, C. (2015) Optimizing crops for biocontrol of pests and disease. Trends in Plant Science, 20, 698-712.

Sterling, W. (1978) Fortuitous biological suppression of the boll weevil by the red imported fire ant. Environmental Entomology, 7, 564-568.

Styrsky, J.D. \& Eubanks, M.D. (2007) Ecological consequences of interactions between ants and honeydew-producing insects. Proceedings of the Royal Society of London Series B: Biological Sciences, 274, 151-164.

Summerlin, J.W., Olson, J.K., Blume, R.R., Aga, A. \& Bay, D.E. (1977) Red imported fire ant effects on Onthophagus gazella and the horn fly. Environmental Entomology, 6, 440-442.

Swift, S., Bryant, J. \& Lanza, J. (1994) Simulated herbivory on Passiflora incarnata causes increased ant attendance. Bulletin of the Ecological Society of America, 75, 225.

Thomson, L.J., McKenzie, J., Sharley, D.J., Nash, M.A., Tsitsilas, A. \& Hoffmann, A.A. (2010) Effect of woody vegetation at the landscape 
scale on the abundance of natural enemies in Australian vineyards. Biological Control, 54, 248-254.

Tilman, D. (1978) Cherries, ants and tent caterpillars: timing of nectar production in relation to susceptibility of caterpillars to ant predation. Ecology, 59, 686-692.

Tilney, M. \& Van Wyk, A.E. (2004) Extrafloral nectaries in Combretaceae: morphology, anatomy and taxonomic significance. Bothalia, 34, 115126.

Torres-Hernandez, L., Rico-Gray, V., Castillo-Guevara, C. \& Vergara, J.A. (2000) Effect of nectar-foraging ants and wasps on the reproductive fitness of Turnera ulmifolia (Turneraceae) in a coastal sand dune in Mexico. Acta Zoologica Mexicana, 81, 13-21.

Tscharntke, T., Bommarco, R., Clough, Y., Crist, T.O., Kleijn, D., Rand, T.A., Tylianakis, J.M., Nouhuys, S.V. \& Vidal, S. (2007) Conservation biological control and enemy diversity on a landscape scale. Biological Control, 43, 294-309.

Turner, M. (1995) Foliar defenses and habitat adversity of three woody plant communities in Singapore. Functional Ecology, 9, 279-284.

Turner, G.W. \& Lersten, N.R. (1981) Unusual foliar nectaries in pomegranate (Punica granatum: Punicaceae). Proceedings of the Iowa Academy of Science, 88, 9.

Van Mele, P., Nguyen, C., Seguni, Z., Camara, K. \& Offenberg, J. (2009) Multiple sources of local knowledge: a global review of ways to reduce nuisance from the beneficial weaver ant Oecophylla. International Journal of Agricultural Resources, Governance and Ecology, 8, 484-504.

Wackers, F.L. \& Bezemer, T.M. (2003) Root herbivory induces an aboveground indirect defence. Ecology Letters, 6, 9-12.

Wäckers, F.L. \& Bonifay, C. (2004) How to be sweet? Extrafloral nectar allocation by Gossypium hirsutum fits optimal defense theory predictions. Ecology, 85, 1512-1518.

Wäckers, F.L. \& Wunderlin, R. (1999) Induction of cotton extrafloral nectar production in response to herbivory does not require a herbivore-specific elicitor. Entomologia Experimentalis et Applicata, 91, 149-154.

Wagner, D. \& Kay, A. (2002) Do extrafloral nectaries distract ants from visiting flowers? An experimental test of an overlooked hypothesis. Evolutionary Ecology Research, 4, 293-305.

Wang, G.W., Tian, J.C., Zhu, P.Y., Zheng, X.S., Xu, H.X., Yang, Y.J. \& Lu, Z.X. (2014) Effects of sugar-rich foods on the longevity, fecundity and pest control capacity of arthropod natural enemies. Acta Entomologica Sinica, 57, 979-990.

Wilder, S.M., Holway, D.A., Suarez, A.V., LeBrun, E.G. \& Eubanks, M.D. (2011) Intercontinental differences in resource use reveal the importance of mutualisms in fire ant invasions. Proceedings of the National Academy of Science, 108, 20639-20644.

Wilson, E.O. (1996) Hawaii: a world without social insects. Bishop Museum Occasional Papers, 45, 3-7.

Yamawo, A., Suzuki, N., Tagawa, J. \& Hada, Y. (2012) Leaf ageing promotes the shift in defence tactics in Mallotus japonicas from direct to indirect defence. Journal of Ecology, 100, 802-809.

Yee, W.L. (2008) Feeding substrates and behaviors of western cherry fruit fly (Diptera: Tephritidae). Environmental Entomology, 37, 172-180.

Yu, D.W. \& Pierce, N.E. (1998) A castration parasite of an ant-plant mutualism. Proceedings of the Royal Society of London Series B: Biological Sciences, 265, 375-382.

Zhu, P.Y., Gurr, G.M., Lu, Z.X., Heong, K.L., Chen, G.H., Zheng, X.S., Xu, H.X. \& Yang, Y.J. (2013) Laboratory screening supports the selection of sesame (Sesamum indicum) to enhance Anagrus spp. parasitoids (Hymenoptera: Mymaridae) of rice planthoppers. Biological Control, 64, 83-89.

Zimmermann, J.G. (1932) Über die extraflorale Nectarien der Angiospermen. Beihefte zum Botanishes Centralblatt, 49, 99-196.

Received 26 May 2016; accepted 16 August 2016

Handling Editor: Sarah Diamond 